\title{
Metal organics vapour phase epitaxy of GaAs : Raman studies of complexes formation
}

\author{
A. Tromson Carli $\left({ }^{+}, *\right)$, P. Gibart $(*)$, R. Druilhe $\left({ }^{+, *}\right)$, Y. Monteil $\left({ }^{* *}\right)$, J. Bouix $\left({ }^{* *}\right)$ and B. El Jani $\left({ }^{*}\right)$ \\ (*) Laboratoire de Physique du Solide et Energie Solaire, CNRS - Sophia Antipolis, 06560 Valbonne, France \\ $\left.{ }^{* *}\right)$ Université Claude Bernard, Laboratoire de Physicochimie Minérale, 69522 Villeurbanne, France
}

(Reçu le 14 janvier 1985, révisé le 22 avril, accepté le 30 avril 1985)

\begin{abstract}
Résumé. - Le remplacement de l'arsine par le triméthylarsenic (TMAs) lors de l'épitaxie en phase vapeur à partir d'organométalliques (EPVOM) de GaAs conduit à des matériaux ayant un résiduel élevé $\left(\sim 10^{17} \mathrm{~cm}^{-3}\right)$. La spectroscopie Raman montre qu'il se forme un solide relativement stable entre le triméthylgallium (TMG) et l'arsine, alors qu'il ne s'en forme pas entre TMG et TMAs. Ce fait pourrait expliquer l'incorporation élevée de carbone lors de l'EPVOM de GaAs en utilisant TMAs.
\end{abstract}

Abstract. - The use of trimethylarsenic(TMAs) in place of arsine in metal organics vapour phase epitaxy (MOVPE) of GaAs gives samples with high residual doping $\left(\sim 10^{17} \mathrm{~cm}^{-3}\right)$. Raman spectroscopy shows that a rather stable solid is formed between trimethylgallium (TMG) and $\mathrm{AsH}_{3}$, whereas no adduct is formed between TMG and TMAs. This feature could explain the high density of residual carbon when using TMAs in MOVPE of GaAs.

\section{Introduction.}

Metal organics vapour phase epitaxy (MOVPE) has proved to be a suitable method to grow electronic quality $\mathrm{GaAs}$ and to manufacture GaAs devices including solar cells, dh lasers, QW structures, superlattices...

$\mathrm{GaAs}$ epilayers grown by MOVPE from $\mathrm{Ga}\left(\mathrm{CH}_{3}\right)_{3}$ (TMG) and $\mathrm{AsH}_{3}$ exhibit reliable electronic properties. With high purity starting $\mathrm{AsH}_{3}$ and redistillated $\mathrm{Ga}\left(\mathrm{CH}_{3}\right)_{3}$ several groups [1, 2] reached $150000 \mathrm{~cm}^{2} /$ V.s for $\mu_{77}$ with a residual concentration of impurities $N_{\mathrm{D}}-N_{\mathrm{A}} \sim 10^{14} \mathrm{~cm}^{-3}$.

Beside TMG and $\mathrm{AsH}_{3}$, other metal organics could be used :

- $\mathrm{Ga}\left(\mathrm{C}_{2} \mathrm{H}_{5}\right)_{3}$ (TEG) $[3,4]$

- $\left(\mathrm{CH}_{3}\right)_{3} \mathrm{Ga} \mathrm{O}\left(\mathrm{C}_{2} \mathrm{H}_{6}\right)_{2}$ or $\mathrm{Ga}\left(\mathrm{C}_{2} \mathrm{H}_{5}\right)_{2} \mathrm{Cl}$

- $\mathrm{As}\left(\mathrm{CH}_{3}\right)_{3}[6,7]$ or $\cdot \mathrm{As}\left(\mathrm{C}_{2} \mathrm{H}_{5}\right)_{3}[6]$.

Even complex molecules, such as $\mathrm{GaAsEt}_{5} \mathrm{Cl}$ [8], containing both $\mathrm{Ga}$ and As atoms could be successfully used to grow GaAs epilayers. The nature of the

$\left({ }^{+}\right)$Permanent address : CNRS, 92195 Meudon Principal, France. residual impurities is dominated both by the purity of the starting metalorganic and the nature of the process involved in the pyrolysis. In other words, residual impurities could result from one atom of the starting molecules (i.e. $\mathrm{C}$ from the $\mathrm{CH}_{3}$ group or $\mathrm{Cl}$ from halides). Reaction mecanisms in MOVPE are not known in details yet. Mass spectrometry [10] and infrared spectroscopy $[11,12]$ were used to analyse, in situ, the gas phase composition in a MOVPE reactor.

\section{GaAs from TMG and AsH $\mathrm{A}_{3}$.}

1.1 Residual Carbon. - $\mathrm{Zn}, \mathrm{Si}$, and $\mathrm{C}$ are the most common among residual impurities in MOVPE GaAs epilayers grown from TMG and $\mathrm{AsH}_{3}$.

$\mathrm{C}$ is unambiguously identified in photoluminescence spectra by two specific peaks : $\mathrm{a}\left(\mathrm{e}, \mathrm{C}^{\circ}\right)$ recombination peak at $1.4934 \mathrm{eV}$ and $\mathrm{a}\left(\mathrm{D}^{\circ}, \mathrm{C}^{\circ}\right)$ at $1.490 \mathrm{eV}$ (Fig. 1a). Another peak at $1.479 \mathrm{eV}$ was found in PL spectra of GaAs grown with large As/Ga ratio $(\sim 30)$ or with excess $\mathrm{CH}_{4}$. This peak was assigned to carbon acceptor in an unidentified form [9]. 


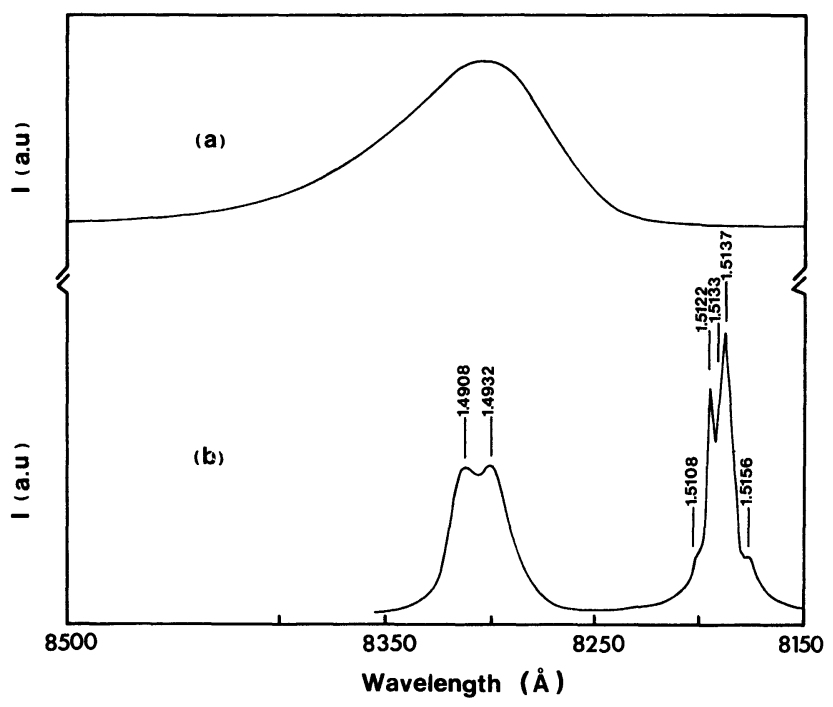

Fig. 1. - 4.2 photoluminescence spectra of GaAs grown by MOVPE from TMG and $\mathrm{AsH}_{3}$ (a); TMG and $\mathrm{As}\left(\mathrm{CH}_{3}\right)_{3}$ (b). The sample (a) was prepared at $630^{\circ} \mathrm{C}$, with $\mathrm{As} / \mathrm{Ga}=10$, $P_{\text {TMG }}=8.5 \mathrm{~Pa}$. The residual concentration of impurities was $N_{\mathrm{D}}-N_{\mathrm{A}}=4 \times 10^{14} \mathrm{~cm}^{-3}$ with $\mu_{77 \mathrm{~K}}=40000 \mathrm{~cm}^{2} / \mathrm{V}$.s. The spectrum (a) exhibits well defined near band gap excitonic complexes : $1.5156 \mathrm{eV}(\mathrm{FE}), 1.5137\left(\mathrm{D}^{\mathrm{o}}, \mathrm{X}\right), 1.5133$ $\left(\mathrm{D}^{\mathrm{o}}, \mathrm{h}\right), 1.5122\left(\mathrm{~A}^{\mathrm{o}}, \mathrm{X}\right)$ and $1.5108 \mathrm{eV}, \mathrm{g}$ exciton. Furthermore the PL spectra show two peaks associated to carbon acceptors : $1.4932 \mathrm{eV}\left(\mathrm{D}^{\circ}, \mathrm{C}^{\circ}\right)$ and $1.4908\left(\mathrm{e}, \mathrm{C}^{\circ}\right)$ recombination. The sample (b) was prepared at $630^{\circ} \mathrm{C}$, with $\mathrm{As} / \mathrm{Ga}=10$, $P_{\text {TMG }}=12.6 \mathrm{~Pa}$. The free donor concentration was $1.4 \times$ $10^{17} \mathrm{~cm}^{3}$ with $\mu_{300 \mathrm{~K}}=3100 \mathrm{~cm}^{2} / \mathrm{V}$.s. The near band gap peak is broad and very weak. The mean feature of this spectrum is the huge broad acceptor peak, $\left(\mathrm{D}^{\circ}, \mathrm{C}^{\circ}\right)$ and $\left(\mathrm{e}, \mathrm{C}^{\circ}\right)$ are not separated, the broadening of these recombination peaks is due to the high density of residual carriers. The two PL spectra were chosen to compare GaAs layers grown with the same As/Ga ratio, at the same temperature. However, in MOVPE of GaAs from TMG and $\mathrm{As}\left(\mathrm{CH}_{3}\right)_{3}$, better spectra were obtained with $\mathrm{As} / \mathrm{Ga}=2$ [17] whereas starting from TMG and $\mathrm{AsH}_{3}$ the best layers were grown using $\mathrm{As} / \mathrm{Ga}=25$.
1.2 GaAs GROWTH WITH EXCESS $\mathrm{CH}_{4}$. - Excess $\mathrm{CH}_{4}$ in the vapour phase results in the growth of compensated samples. $\mathrm{C}$ is probably incorporated both as donors and acceptors. Besides the usual $\left(\mathrm{e}, \mathrm{C}^{\mathrm{o}}\right)$ and $\left(\mathrm{D}^{\circ}, \mathrm{C}^{\circ}\right)$ recombination peaks, PL spectra show an enhanced peak at $1.479 \mathrm{eV}$ [9]. Furthermore the addition of $\mathrm{CH}_{4}$ changes the growth velocity. For $P_{\mathrm{CH}_{4}} \gtrsim 10 \mathrm{~Pa}$ the growth process becomes kinetically controlled [9].

1. 3 INCORPORATION OF C IN GaAs. - C in MOVPE $\mathrm{GaAs}$ arises from methyl radicals. Several elementary processes can be hypothesized :

i) incorporation of $\mathrm{C}$ from adsorbed $\mathrm{CH}_{4}$ molecules (TMG decomposes into $\mathrm{CH}_{4}$ );

ii) formation in the gas phase of an adduct $\mathrm{Ga}\left(\mathrm{CH}_{3}\right)_{3}-\mathrm{AsH}_{3}$ and decomposition at the substrate of this adduct;

iii) decomposition of $\mathrm{Ga}\left(\mathrm{CH}_{3}\right)_{3}$ into $\mathrm{GaCH}_{3}$ and adsorption of $\mathrm{CH}_{3}$ radicals at As sites [10].

At this point in time no direct answer is evident. A non intrusive, non destructive method of in situ investigation is needed for a better understanding of the processes involved in the pyrolysis of TMG and $\mathrm{AsH}_{3}$. Raman spectroscopy can give direct information about the nature and concentration of gaseous species. As a preliminary study of processes involved in MOVPE by in situ Raman spectroscopy, we studied the thermal behaviour of Raman spectra of TMG, $\mathrm{AsH}_{3}$, TMAs and mixtures TMG-AsH $\mathrm{TH}_{3}$, TMG-TMAs which were kept in closed silica cells.

1.4 THERMAL DEPENDENCE OF RAMAN SPECTRA OF TMG, $\mathrm{AsH}_{3}$ AND TMG $+\mathrm{AsH}_{3}$.

1.4.1 TMG. - The Raman spectrum in gas phase of $\mathrm{Ga}\left(\mathrm{CH}_{3}\right)_{3}$ at $100{ }^{\circ} \mathrm{C}$ is presented in figure $2 . \mathrm{Ga}\left(\mathrm{CH}_{3}\right)_{3}$ which is monomeric in the gas phase with a planar

TMG $-100^{\circ} \mathrm{C}$

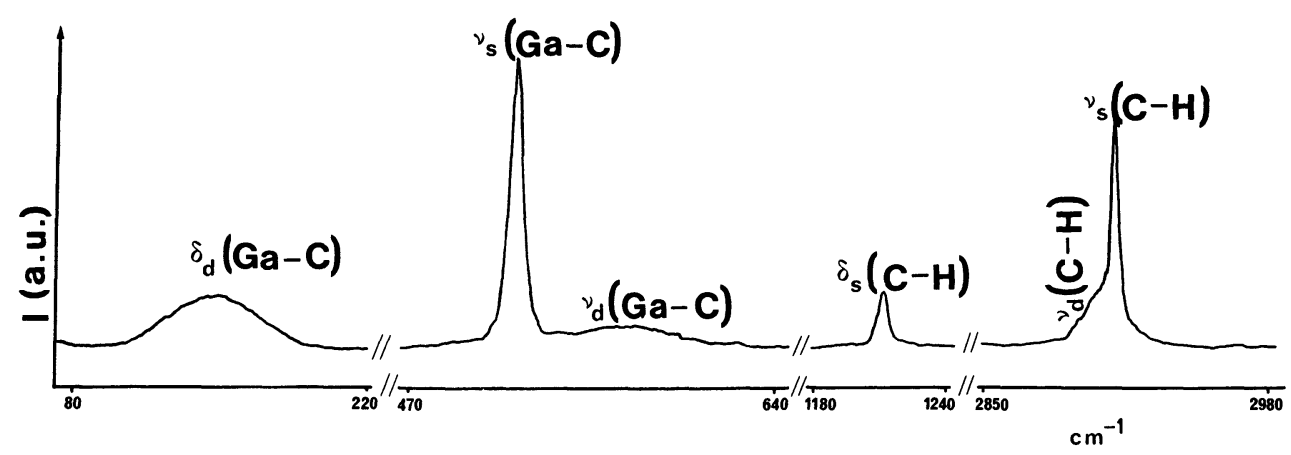

Fig. 2. - Raman spectrum of TMG at $100^{\circ} \mathrm{C}$. 
$\mathrm{GaC}_{3}$ skeleton, belongs to the point group $\mathrm{D}_{3 \mathrm{~h}}$. Therefore the vibrational assignments are :

$$
\begin{aligned}
& \delta_{\mathrm{d}(\mathrm{Ga}-\mathrm{C})\left(\mathrm{E}^{\prime}\right)}=146 \mathrm{~cm}^{-1} \\
& v_{\mathrm{s}(\mathrm{Ga}-\mathrm{C})\left(\mathrm{A}^{\prime}\right)}=521 \mathrm{~cm}^{-1} \\
& v_{\mathrm{d}(\mathrm{Ga}-\mathrm{C})\left(\mathrm{E}^{\prime}\right)}=562 \mathrm{~cm}^{-1} .
\end{aligned}
$$

The other bands arise from motions of the methyl groups

$$
\begin{aligned}
& \delta_{\mathrm{s}(\mathrm{C}-\mathrm{H})}=1204 \mathrm{~cm}^{-1} \\
& v_{\mathrm{d}(\mathrm{C}-\mathrm{H})}=2907 \mathrm{~cm}^{-1} \\
& v_{\mathrm{s}(\mathrm{C}-\mathrm{H})}=2914 \mathrm{~cm}^{-1} .
\end{aligned}
$$

TMG starts to decompose at about $250^{\circ} \mathrm{C}$. This gives only $\mathrm{CH}_{4}$, no $\mathrm{H}_{2}$ and there were no other hydrocarbons detected.

1.4.2 $\mathrm{AsH}_{3} .-\mathrm{AsH}_{3}$, with symmetry $\mathrm{C}_{3 v}$, gives four bands :

$$
\begin{aligned}
& v_{\mathrm{s}(\mathrm{As}-\mathrm{H})\left(\mathrm{A}_{1}\right)}=2114 \mathrm{~cm}^{-1} \text { (strong) } \\
& v_{\mathrm{d}(\mathrm{As}-\mathrm{H})(\mathrm{E})}=2126 \mathrm{~cm}^{-1} \text { (medium) } \\
& \delta_{\mathrm{s}(\mathrm{As}-\mathrm{H})\left(\mathrm{A}_{1}\right)}=990 \mathrm{~cm}^{-1} \text { (weak) } \\
& \delta_{\mathrm{d}(\mathrm{As}-\mathrm{H})(\mathrm{E})}=898 \mathrm{~cm}^{-1}\left({ }^{\prime \prime}\right) .
\end{aligned}
$$

$\mathrm{AsH}_{3}$ is stable up to $150^{\circ} \mathrm{C}$. At higher temperatures, $\mathrm{H}_{2}$ will appear and at $400{ }^{\circ} \mathrm{C}, \mathrm{AsH}_{3}$ is completely decomposed into $\mathrm{As}_{4}$ and $\mathrm{H}_{2}$.
1.4.3 TMG $+\mathrm{AsH}_{3}$. - Raman cells are first filled with TMG, then cooled down to liquid nitrogen temperature. Afterwards $\mathrm{AsH}_{3}$ is added and the cell sealed off. Several mixtures were made around the stoichiometric composition $1: 1$.

When mixing TMG and $\mathrm{AsH}_{3}$ even as low as to $1013 \mathrm{~Pa}$, a white solid is formed that decomposes under laser impact. This solid is stable enough to be isolated, but looks inhomogeneous and its colour becomes yellow with time. The results of the microanalysis are (weight \%) :

$$
\begin{array}{rlrl}
\mathrm{Ga} & =51.44 \% & \text { As } & =36.44 \% \\
\mathrm{C} & =10.07 \% & \mathrm{H} & =2.77 \% .
\end{array}
$$

This solid is slowly formed from a liquid phase after spontaneous separation of gas phase. The Raman analysis of the gaseous phase above the solid gives $\mathrm{CH}_{4}$.

Then the bulk reaction which occurs may be written :

$4 \mathrm{AsH}_{3}+6 \mathrm{Ga}\left(\mathrm{CH}_{3}\right)_{3} \rightarrow \mathrm{As}_{4} \mathrm{Ga}_{6} \mathrm{C}_{7} \mathrm{H}_{22}+11 \mathrm{CH}_{4}$.

This solid may be a mixture, it is also possible that a slow polymerization process may take place and it is very moisture sensitive.

Raman [13] and I.R. spectra [14] (Figs. 3a-b) of this solid has been recorded. Vibrational assignments are

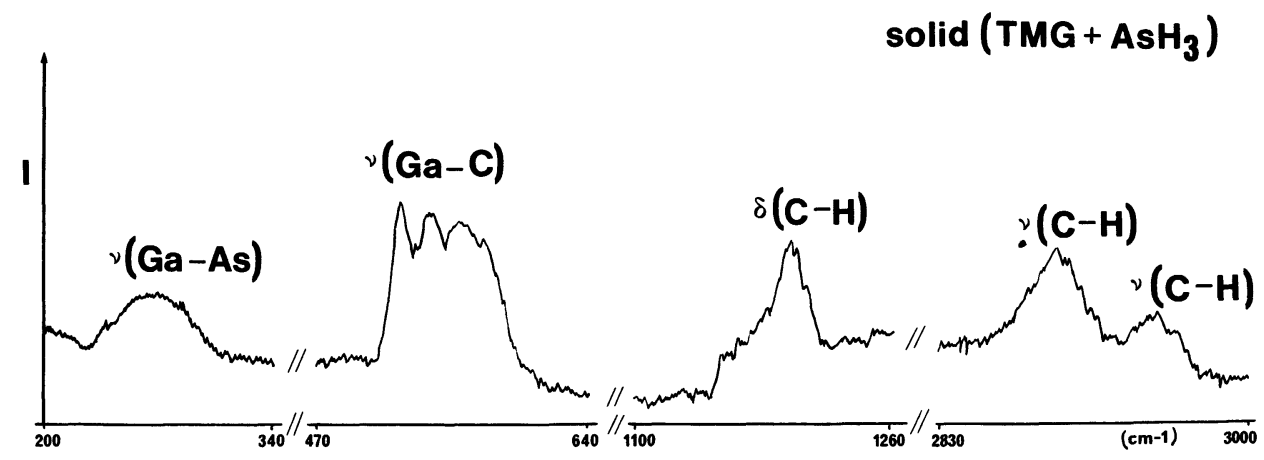

Fig. 3a. - Raman spectrum of the solid obtained in closed cells from TMG and $\mathrm{AsH}_{3}$, temperature of the cell $100^{\circ} \mathrm{C}$.

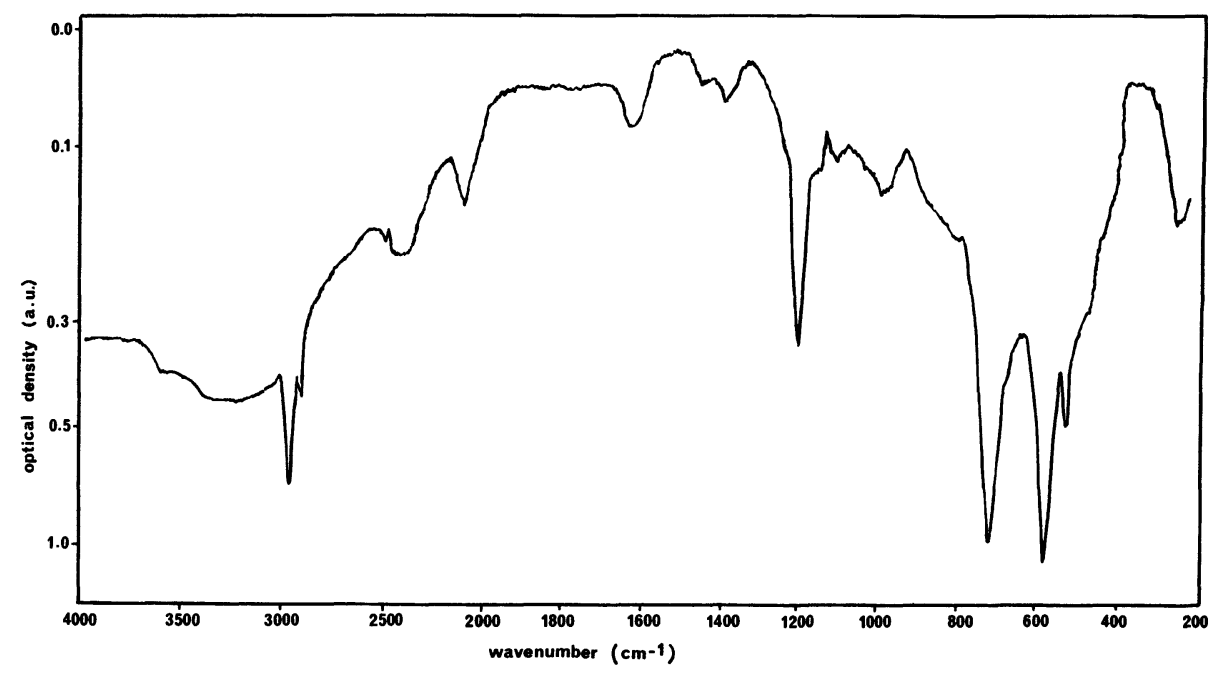

Fig. 3b. - IR spectrum of this solid. 
difficult to assess for this solid (Table I). The only certainty is the existence of a band for the Ga-As bond at $266 \mathrm{~cm}^{-1}$, since for $\mathrm{GaAs}$ we have found the same value for $v_{s}(\mathrm{GaAs})$.

Table I. - Observed spectra of solid (TMG $\left.+\mathrm{AsH}_{3}\right)$.

\begin{tabular}{|c|c|c|}
\hline $\begin{array}{l}\text { Raman } \\
\text { (solid) }\end{array}$ & $\begin{array}{c}\text { Infrared } \\
\text { (CsBr, pellet) }\end{array}$ & Assignments \\
\hline- & - & - \\
\hline 266 & 255 & $v_{(\mathrm{Ga}-\mathrm{As})}$ \\
\hline 521 & $\left.\begin{array}{l}- \\
595 \\
735 \\
995\end{array}\right\}$ & $v_{(\mathrm{Ga}-\mathrm{C})}$ \\
\hline $\begin{array}{l}1145 \\
1202\end{array}$ & $\begin{array}{ll}1 & 215 \\
1 & 410 \\
1 & 465 \\
2 & 110\end{array}$ & $\delta_{(\mathrm{C}-\mathrm{H})}$ \\
\hline $\begin{array}{l}2906 \\
2968\end{array}$ & $\left.\begin{array}{l}2910 \\
2965\end{array}\right\}$ & $\begin{array}{l}v_{(\mathbf{A s}-\mathrm{H})} \\
v_{(\mathbf{C}-\mathrm{H})}\end{array}$ \\
\hline
\end{tabular}

The decomposition of this solid was deduced from the temperature dependence of Raman spectra of gases in equilibrium with the solid. Decomposition starts at $350{ }^{\circ} \mathrm{C}$ and $\mathrm{CH}_{4}$ is the only gas which comes from the decomposition of the solid. This was not the behaviour reported by Ring and Schlyer [15]. However, the experimental conditions were different. In their experiment the reaction occurred in contact with GaAs and at higher temperature, the complex formed was probably different.

The main feature deduced from the present Raman studies is the existence of (a) rather stable solid compound(s) formed between TMG and $\mathrm{AsH}_{3}$. This solid results from the mixing of TMG and $\mathrm{AsH}_{3}$ by elimination of $\mathrm{CH}_{4}$ molecules. These results cannot be - of course - directly extrapolated to reactions occurring in the gas phase. Anyhow recent studies have shown that $\mathrm{AsH}_{3}$ decomposition is enhanced by TMG addition $[10,11]$. In the vapour phase the adduct is likely formed or some intermediate complex formed by the elimintion of $\mathrm{CH}_{4}$ molecules and the incorporation of carbon occurs via the incomplete desorption of $\mathrm{CH}_{3}$ groups at the interface. These $\mathrm{CH}_{3}$ groups may belong to $\mathrm{Ga}-\mathrm{As}-\mathrm{CH}_{3}$ complexes [16].

\section{GaAs from TMG and $\mathrm{As}\left(\mathrm{CH}_{3}\right)_{3}$ (TMAs).}

$\mathrm{AsH}_{3}$ can be replaced by $\mathrm{As}\left(\mathrm{CH}_{3}\right)_{3}$ in MOVPE of $\mathrm{GaAs}$. The danger of using highly poisonous $\mathrm{AsH}_{3}$ is somewhat reduced when using the rather stable metalorganic $\mathrm{As}\left(\mathrm{CH}_{3}\right)_{3}$. Moreover, using TMAs may overcome the problem of formation of stable adducts when growing In compounds. GaAs layers were grown from TMG and TMAs. The main growth parameters were deposition temperature and the ratio $\mathrm{As} / \mathrm{Ga}$ in the gas phase, partial pressure of TMG. Some experiments were carried out at reduced pressure.

2.1 ResiduAl DOPING. - Whatever the ratio As/Ga (in the range 2-40) all other growth conditions kept constant : $T_{\mathrm{D}}=630^{\circ} \mathrm{C}$, operating pressure $10^{5} \mathrm{~Pa}$, total $\mathrm{H}_{2}$ flow $5 \mathrm{l} / \mathrm{min}, P_{\mathrm{TMG}}=12.6 \mathrm{~Pa}$, the residual doping remains high : $N_{\mathrm{D}}-N_{\mathrm{A}} \sim 2 \times 10^{17} \mathrm{~cm}^{-3}$, $\mu_{300} \sim 3000 \mathrm{~cm}^{2} / \mathrm{V}$.s and the compensation ratio is about 0.6. This means that donor and acceptor impurities are incorporated at densities of the order of $2-4 \times 10^{17} \mathrm{~cm}^{-3}$. The most likely acceptor impurity is C. As in the TMG-AsH ${ }_{3}$ standard method $N_{\mathrm{D}}$ and $N_{\mathrm{A}}$ increases with $T_{\mathrm{D}}$ and the ratio As/Ga. Low pressure deposition results in even higher residual doping levels [17].

The 4.2 K PL spectra show unsolved features near the band edge together with very broad acceptor peaks (Fig. 1b).

2.2 Thermal DePENDENCE OF RAMAN SPECTRA OF TMAs AND TMG + TMAs. - $\mathrm{As}\left(\mathrm{CH}_{3}\right)_{3}$ with a supposed $\mathrm{AsC}_{3}$ skeleton has the point group $\mathrm{C}_{3 \mathrm{v}}$. Therefore the vibrational assignements are :

$$
\begin{aligned}
& \delta_{\mathrm{d}(\mathrm{As}-\mathrm{C})[\mathrm{E}]}=230 \mathrm{~cm}^{-1} \\
& v_{\mathrm{s}(\mathrm{As}-\mathrm{C})\left[\mathrm{A}_{1}\right]}=570 \mathrm{~cm}^{-1} \\
& v_{\mathrm{d}(\mathrm{As}-\mathrm{C})[\mathrm{E}]}=590 \mathrm{~cm}^{-1} .
\end{aligned}
$$

Furthermore the bands from the motions of the methyl group are :

$$
\begin{aligned}
& \delta_{\mathrm{s}(\mathrm{C}-\mathrm{H})}=1260 \mathrm{~cm}^{-1} \\
& v_{\mathrm{d}(\mathrm{C}-\mathrm{H})}=2907 \mathrm{~cm}^{-1} \\
& v_{\mathrm{s}(\mathrm{C}-\mathrm{H})}=2914 \mathrm{~cm}^{-1} .
\end{aligned}
$$

TMAS remains stable up to $300^{\circ} \mathrm{C}$. A mixture TMG + TMAs $(1 \mathrm{kPa})$ was placed in a sealed quartz cell for Raman analysis. The Raman spectrum (Fig. 4) is just the superposition of the TMG and TMAs spectra (Fig. 4). There is no evidence of adduct formation. Starting from $200^{\circ} \mathrm{C}$, the intensities of the above mentioned peaks starts to decrease. No new compound correlatively appears.

2.3 Preliminary CONClusions. - It is well established that $\mathrm{Ga}\left(\mathrm{CH}_{3}\right)_{3}$ and $\mathrm{As}\left(\mathrm{CH}_{3}\right)_{3}$ form an adduct with lower vapour pressure than the constituents [18]. However, in the experimental conditions used in Raman spectroscopy $\left(1000 \mathrm{~Pa}, 100^{\circ} \mathrm{C}\right)$ the adduct is already dissociated. It can be extrapolated from the present Raman studies that $\mathrm{As}$ and $\mathrm{Ga}$ atoms are separately brought to the growing interface and that $\mathrm{CH}_{4}$ molecules arising from the decomposition of TMG and TMAs should desorb. The high concentration of $\mathrm{CH}_{3}$ radicals at the interface is likely a source of $\mathrm{C}$ in the layers. 


\section{$100^{\circ} \mathrm{C}$}

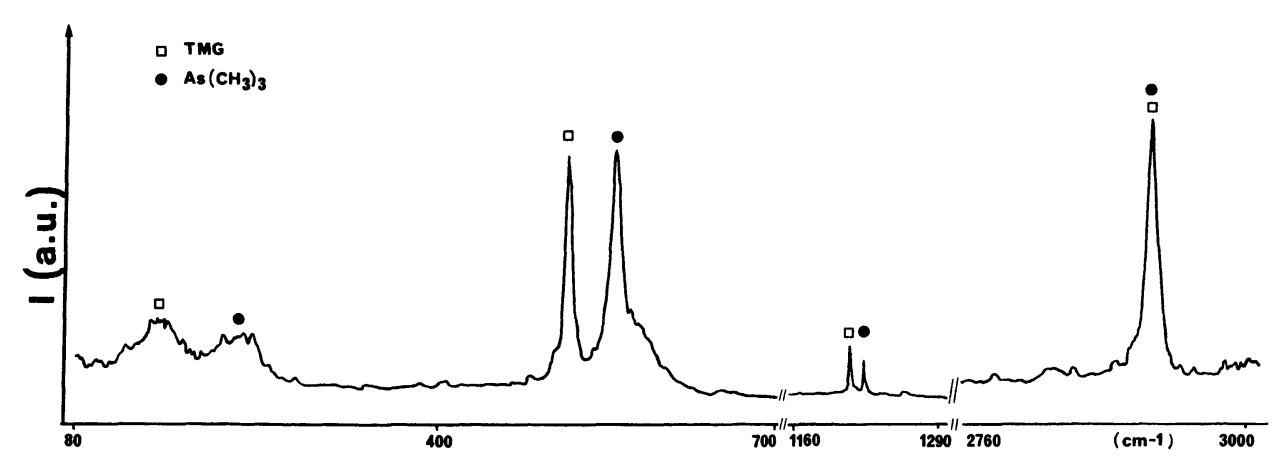

Fig. 4. - Raman spectrum of a mixture TMG and $\mathrm{As}\left(\mathrm{CH}_{3}\right)_{3}\left(100^{\circ} \mathrm{C}, 1 \mathrm{kPa}\right)$. The spectrum is only the superposition of TMG and $\mathrm{As}\left(\mathrm{CH}_{3}\right)_{3}$ spectra.

\section{GaAs from $\mathrm{Ga}\left(\mathrm{C}_{2} \mathrm{H}_{5}\right)_{3}$ and $\mathrm{AsH}_{3}$.}

Published results $[3,4]$ reported high mobility materials. It was pointed out that carbon incorporation is limited, in low temperature PL spectra $\left(\mathrm{C}^{\circ}, \mathrm{D}^{\circ}\right)$ and $\left(\mathrm{e}, \mathrm{C}^{\circ}\right)$ recombination peaks do not appear. The pyrolysis of $\mathrm{Ga}\left(\mathrm{C}_{2} \mathrm{H}_{5}\right)_{3}$ produces $\mathrm{C}_{2} \mathrm{H}_{6}$ which prevents $\mathrm{C}$ to be incorporated in the $\mathrm{GaAs}$ growing layer.

\section{Other metal organics.}

GaAs grown from unusual metalorganics present a high level of residual impurities : $10^{17}$ to $10^{18} \mathrm{~cm}^{-3}$. These uncommon metalorganics are not available with " electronic " purity. Furthermore the pyrolysis of these compounds results in the incorporation of atoms belonging to the starting metalorganic : $\mathrm{Cl}, \mathrm{O}, \mathrm{C}$.

$\mathrm{GaAs}$ grown from $\mathrm{GaMe}_{2} \mathrm{ClAsEt}_{3}$ or $\mathrm{GaEt}_{2}$ $\mathrm{ClAsEt}_{3}$ contains significant amount of carbon as showed by Auger spectroscopy [19].

\section{Discussion.}

The Raman spectroscopy experiments were carried out in closed cells without $\mathrm{H}_{2}$ dilution. They cannot be directly extrapolated to real epitaxial systems. In a future extension of this exploratory study, in situ Raman spectroscopy will be developed. Anyhow, from these preliminary results the following conclusions can be driven :

$-\mathrm{C}$ is incorporated when $\mathrm{CH}_{3}$ radicals (or $\mathrm{CH}_{4}$ molecules) are present.

- A stable solid compound is formed between $\mathrm{Ga}\left(\mathrm{CH}_{3}\right)_{3}$ and $\mathrm{AsH}_{3}$ (in closed cells down to $1 \mathrm{kPa}$ ). A " compound " is likely to be formed in the vapour phase in a MOVPE reactor. Nishizawa et al. [11] studied the reaction mechanism of GaAs formation in MOVPE using IR spectroscopy, they pointed out the existence of a « compound » of unknown composition between TMG and $\mathrm{AsH}_{3}$ even at concentrations of the order of $10 \mathrm{~Pa}$. On the other hand no stable adduct was evidenced between $\mathrm{Ga}\left(\mathrm{CH}_{3}\right)_{3}$ and $\mathrm{As}\left(\mathrm{CH}_{3}\right)_{3}$ in closed cells (down to $1 \mathrm{kPa}$ ) and is probably not formed is the gas phase.

- Due to high thermal gradient in the reactor near the susceptor, the "compound" formed in the gas phase between TMG and $\mathrm{AsH}_{3}$ is probably brought very close to the surface of the substrate before decomposition. In the MOVPE of GaAs from TMG and TMAs, Ga and As atoms are separately brought to the growing interface.

- The incorporation of $\mathrm{C}$ in $\mathrm{GaAs}$ results from the incomplete desorption of $\mathrm{CH}_{3}$ radicals. In the case of MOVPE from TMG and $\mathrm{AsH}_{3}$, it has been hypothesized that growth occurs via As- $\mathrm{Ga}-\mathrm{CH}_{3}$ complexes, this could explain the growth anisotropy [16] and the anisotropic incorporation of carbon atoms [20]. In the MOVPE of GaAs from TMG and TMAs no ternary complex may be formed; growth occurs via incorporation of $\mathrm{Ga}$ and As atoms separately (or $\mathrm{GaCH}_{3}$ and $\mathrm{AsCH}_{3}$ radicals). $\mathrm{As}\left(\mathrm{CH}_{3}\right)_{3}$ is rather stable metalorganic; the bond strength of As-C in TMAs (55 kcal), can be compared to Ga-C in TMG $(59 \mathrm{kcal})$. A high density of $\mathrm{CH}_{3}$ radicals bound to the surface results in carbon incorporation to a much greater extend that in the TMG-AsH ${ }_{3}$ system.

- Finally, in the MOVPE of GaAs from TEG and $\mathrm{AsH}_{3}$ no data on stability of the adduct exist. However, TEG decomposes giving $\mathrm{C}_{2} \mathrm{H}_{6}$, which cannot be incorporated in the growing layer for steric features. Low temperature photoluminescence spectra of $\mathrm{GaAs}$ grown from TEG and $\mathrm{AsH}_{3}$ do not present $(\mathrm{D}, \mathrm{A})$ and $\left(\mathrm{e}, \mathrm{A}^{\mathrm{o}}\right)$ recombination peaks due to carbon [3].

Great progress in the understanding of the MOVPE reaction mechanisms is expected from in situ investigation methods like IR, UV or Raman spectroscopy. 
In addition, the temperature profile in an MOVPE reactor can be studied by means of rotational Raman scattering of $\mathrm{H}_{2}$.

\section{Acknowledgments.}

The very first Raman spectra in closed cells were done at 1. "Physikalischen Institut - Aachen " by
Dr A. Selmi and Dr R. Dornhaus and reported in B. El Jani thesis. The authors wish to express them their thanks. Helpful advices were provided by Dr A. Lautié from the "Laboratoire de Spectrochimie Infrarouge et Raman - CNRS - Vitry ». The authors like to acknowledge Pr. G. Constant for his critical comments. This work was partially supported by DRET under contract 82-34-197.

\section{References}

[1] Nakanisi, T., Udagawa, T., TANaki, A. and KameI, K., J. Crystal Growth 55 (1981) 255.

[2] Hess, K. L., Dapkus, P. D. and Manasevit, H. M., Electronic Mat. Conf. Santa Barbara CA (1981) paper I-1.

[3] Bhat, R., O'Connor, P., Temkin, H., Dingle, R. and Keramidas, V. G., Inst. Phys. Conf. Ser. 63 (1982) 101.

[4] SeKi, Y., TanNo, K., Lida, K. and IchiKi, E., J. Electrochem. Soc. 122 (1975) 1108.

[5] Skvortsov, I. M., Nemirovskiu, L. N., Dutkinat, T. A., Gribov, B. G., Fedorov, V. A. and KozyrKIN, B. J., Izvest. Akad. Nauk. S.S.S.R. Neorg. Mater. 12 (1976) 754.

[6] Nakayama, Y., OHKawa, S., Hashimoto, H., IshiKaWA, H., J. Electrochem. Soc. 123 (1976) 1227.

[7] Ludowise, M. J., CoOper III, C. B., Proc. SPIE. Int. Soc. Opt. Eng., U.S.A. 323 (1982) 117.

[8] Zaouk, A., Salvetat, E., Sakaya, J., Maury, F., Constant, G., J. Crystal Growth 55 (1981) 135 ;

ZAOUK, A., Thesis, INP Toulouse (1983).

[9] El Jani, B., LerouX, M., Grenet, J. Cl. and Gibart, P., J. Phys. C 5 (1982) 303 ;

El Jani, B., Grenet, J. Cl., Leroux, M., Guittard, M., Gibart, P. and Chevallier, J., Revue Phys. Appl. 19 (1984) 7.
[10] Vodjani, N., Thesis, Paris VI (1982).

[11] Nishizawa, J. and Kurabayashi, T., J. Electrochem. Soc. 130 (1983) 413.

[12] Leys, M. R. and Veenvliet, H., J. Crystal Growth 55 (1981) 145.

[13] The Raman spectra were taken with a PHO type CODERG spectrometer provided with a photomultiplier cooled at $253 \mathrm{~K}$ by Peltier effect. An argon laser (Spectra Physics 165) supplies $1600 \mathrm{~mW}$ at a frequency of $20492 \mathrm{~cm}^{-1}$.

[14] The IR spectra were taken with infrared spectrophotometer Perkin Elmer 457.

[15] SChlyer, D. J. and Ring, M. A., J. Electrochem. Soc. 124 (1977) 569 ; J. Organomet. Chem. 119 (1976) 9 ; 71 (1974) 25

[16] Gibart, P., Tromson-Carli, A., Druilhe, R., Second Int. Conf. Metalorganic Vapour Phase Epitaxy, Sheffield UK, April 1984, Abstract book.

[17] A full report on detailed growth of GaAs from TMG and TMAs is available on request.

[18] Cheng, C. H., Jones, K. A. and Motyl, K. M., J. Electron. Mat. 13 (1984) 703.

[19] Zaouk, A., Calson, R. and Constant, G., Ann. Chim. Fr. 9 (1984) 587.

[20] KueCh, T. F. and Venhoff, E., J. Crystal Growth 68 (1984) 148. 